\title{
PENGARUH KOMPETENSI DAN MOTIVASI TERHADAP KINERJA KARYAWAN PERUSAHAAN ASURANSI
}

\author{
Kartika Juanita Nurwin \\ Universitas Negeri Surabaya \\ kartika.17080574137@mhs.unesa.ac.id \\ Agus Frianto \\ Universitas Negeri Surabaya \\ agusfrianto@unesa.ac.id
}

Abstract

This research aims to explain how competence and work motivation affect employee performance in an insurance company. This research use 35 employees at PT. Asuransi Umum Bumi Putera Muda Unit Syariah Surabaya as a sample. Data collection use observations, interviews and (primary) questionnaires. This research uses data analysis of validity, reliability, classic assumption, and hypothesis tests. Data were analyzed by multiple linear regression with SPSS. This research shows that competence and work motivation simultaneously have a significant influence on employee performance. Partially, competence has positive and significant on employee performance. The result shows that the competencies possessed by the employee have an impact on employee performance. As well as role work motivation has positive and not significant on employee performance. The results of data testing show that the work motivation provided by the company has no impact on employee performance. The company must facilitate employees to increase competence and work motivation since employee performance correlates with firm performance.

Keyword: competence; employee perfomance; work motivation.

\section{PENDAHULUAN}

Suatu organisasi dapat berkembang apabila organisasi tersebut dapat meningkatkan kinerja karyawannya (Ainanur \& Tirtayasa, 2018). Setiap organisasi selalu mengharapkan SDM yang mampu berkerja secara efektif dan efisien agar tujuan perusahaan dapat tercapai, sehingga organisasi harus memiliki berbagai cara agar dapat menggali dan memanfaatkan potensi SDM yang dimiliki oleh karyawan (Dwiyanti et al., 2019). Cara-cara tersebut tidak akan berhasil apabila tidak adanya dukungan dari karyawan, dukungan tersebut dapat berupa kompetensi dan motivasi yang dimiliki oleh karyawan, yang mana kompetensi dan motivasi tersebut dapat memengaruhi kinerja dari karyawan (Putu et al., 2016).

Kinerja tidak hanya memiliki arti sebagai prestasi dalam bekerja atau hasil dari pekerjaan, namun kinerja juga dapat diartikan sebagai proses pekerjaan berlangsung (Ainanur et al., 2018). Kinerja karyawan merupakan aspek penting dalam kesuksesan sebuah organisasi, di mana setiap organisasi memerlukan karyawan yang dapat menyelesaikan pekerjaan secara efektif (Lutfiyah et al., 2020). Untuk dapat menyelesaikan pekerjaan secara efektif, perlu adanya pengaturan sumber daya manusia yang baik. Dengan adanya hal itu, maka karyawan akan merasa nyaman dalam melakukan tugasnya sehingga mendapatkan hasil kerja yang maksimal (Ratnasari, 2016). Selain pengelolaan sumber daya yang baik, kinerja karyawan memiliki berbagai macam faktor lain yang dapat memengaruhi hasil dari kinerja karyawan. Faktor kompetensi dan motivasi ialah salah satu faktor yang dapat memengaruhi hasil dari kinerja karyawan (Masinde et al., 2019).

Kompetensi memiliki arti kemampuan yang didasari oleh pengetahuan dan keterampilan yang didukung dengan pelaksanaan tugas dan pekerjaan serta sikap kerja di tempat kerja yang sesuai dengan standar kerja yang diterapkan oleh perusahaan (Sutrisno, 2016). Kompetensi merupakan kombinasi antara pengetahuan dan keterampilan dalam lingkungan manajemen, yang menunjukkan kemampuan fisik dan mental maksimum seseorang dengan karakteristik yang stabil (Putri et al., 2019). Kompetensi berkaitan dengan kegiatan yang dilakukan seseorang di tempat kerja, kompetensi tersebut dapat mengidentifikasi keterampilan, karakteristik, dan pengetahuan yang dibutuhkan oleh 
Kartika Juanita Nurwin \& Agus Frianto. Pengaruh Kompetensi dan Motivasi terhadap Kinerja Karyawan Perusahaan Asuransi

karyawan untuk melaksanakan tugas dan tanggung jawabnya, sehingga dapat mencapai kualitas profesional di tempat kerja (Distyawaty, 2017). Kompetensi membantu karyawan bertindak dengan cara yang terorganisir, objektif, terarah dan bertanggung jawab serta meningkatkan kreativitas, kepekaan, dan kualitas interpersonal yang baik dalam kinerja (Chumba et al., 2018). Kompetensi menggambarkan kemampuan untuk melakukan tugas atau peran dalam perusahaan yang dapat diukur sehingga dapat mengetahui tingkat kinerja karyawan yang diharapkan (Masinde et al., 2019).

Motivasi memiliki bahasa latin movere artinya dorongan atau penggerak. Motivasi adalah bagaimana cara untuk memberikan dorongan kepada karyawannya, agar dapat bekerja secara maksimal (Rosmaini \& Tanjung, 2019). Keinginan yang dimiliki individu dalam melakukan suatu kegiatan tertentu untuk mencapai suatu tujuan ialah suatu dorongan dari keadaan pribadi yang dikatakan sebagai motivasi yang dimiliki oleh individu (Hasyim et al., 2020). Motivasi mengarahkan kemampuan dan kekuatan karyawan untuk dapat berpartisipasi dengan produktif, sehingga mampu mewujudkan serta mencapai tujuan yang diterapkan (Mariati, 2018). Motivasi sebagai sesuatu yang mendorong seseorang untuk bertindak atau berperilaku dengan cara tertentu dan motivasi membuat seseorang memulai, melaksanakan, dan memelihara suatu kegiatan tertentu (Subari \& Raidy, 2015).

Penelitian ini dilakukan di PT. Asuransi Umum Bumi Putera Muda 1967 Unit Syariah Surabaya. Dari hasil wawancara awal, perusahaan tersebut memiliki berbagai macam produk asuransi, sehingga menuntut para karyawan untuk memiliki kompetensi yang unggul dalam menangani berbagai macam produk asuransi. Dengan memiliki komptensi yang unggul, maka karyawan akan dapat menyelesaikan pekerjaannya dengan baik dan dapat menghasilkan kinerja yang baik pula. Kinerja yang baik tidak hanya didapatkan dengan memiliki kompetensi yang unggul saja, melainkan motivasi kerja yang dimiliki karyawan juga berdampak pada kinerja karyawan. Perusahaan selalu berusaha untuk meningkatkan kinerja-kinerja karyawannya melalui pengembangan karir yang berupa peningkatan keahlian dan kompetensi, selain itu perusahaan juga memberikan motivasi kepada karyawannya.

Penelitian ini bertujuan untuk mengetahui bagaimana pengaruh kompetensi dan motivasi terhadap kinerja karyawan perusahaan asuransi.

\section{KAJIAN PUSTAKA DAN PENGEMBANGAN HIPOTESIS}

\section{Kinerja}

Kinerja karyawan dikatakan bersifat individual karena tiap-tiap karyawan mempunyai tingkatan kemampuan yang berbeda-beda untuk melaksanakan tugasnya, oleh karena itu kinerja dari masingmasing karyawan dapat membantu perusahaan untuk mengukur karyawan atas hasil kerjanya (Ainanur \& Tirtayasa, 2018). Hasil dari pekerjaan,baik secara kualitas maupun kuantitas merupakan hasil dari pelaksanaan tanggung jawab dan tugas yang dimiliki oleh karyawan (Wardani, 2017). Kinerja merupakan suatu proses yang dapat diukur dalam waktu tertentu berdasarkan ketentuan dan kesepakatan yang ada (Edison et al., 2017). Kinerja dapat dideskripsikan dengan seberapa jauh kegagalan atau keberhasilan dalam melakukan prosesnya untuk mencapai visi misi organisasi, tujuan serta sasaran tujuan perusahaan. Selain itu kinerja juga memiliki arti mutu dan kuantitas kerja orang untuk mencapai tujuan tertentu (Purba \& Gunawan, 2018). Kinerja karyawan diukur menggunakan indikator dari (Edison et al., 2017) yang memiliki empat indikator yaitu kualitas, kuantitas, ketepatan waktu, dan kerjasama.

\section{Kompetensi}

Kompetensi adalah kapasitas dari karyawan yang sesuai dengan ketetapan perusahaan dan tuntutan pekerjaan yang mengacu pada perilaku, sehingga membawa hasil yang diinginkan. Dengan kata lain kompetensi ialah hal-hal yang dapat membantu seseorang untuk melakukan tugasnya dengan baik (Retningjati et al., 2018). Seseorang yang berprestasi ditempat kerja, memiliki karakteristik yang mendasari perilaku dan menggambarkan karakteristik pribadi, pengetahuan atau keterampilan, motif,dan konsep diri, hal tersebut merupakan sebuah kompetensi dalam diri seseorang (Manda, 2018). Kemampuan yang didasari oleh pengetahuan dan keterampilan yang didukung dengan pelaksanaan tugas dan pekerjaan serta sikap kerja di tempat kerja yang sesuai dengan standar kerja 
yang diterapkan oleh perusahaan merupakan sebuah kompetensi yang harus dimiliki karyawan (Sutrisno, 2016). Indikator yang digunakan dalam mengukur kompetensi adalah mengacu pada (Wibowo, 2014) yang terdapat lima indikator di antaranya sebagai berikut. (1) Motif adalah dorongan untuk melakukan sesuatu hal atau sesuatu yang diinginkan seseorang yang mengakibatkan tindakan. (2) Sifat adalah kepribadian seseorang atau respon yang diberikan seseorang terhadap suatu informasi atau situasi. (3) Konsep diri adalah karakteristik seseorang mulai dari sikap, sifat, nilai, atau citra diri. (4) Pengetahuan ialah sesuatu hal yang diketahui atau dipunyai seseorang sesuai dengan bidang yang dikuasainya. (5) Keterampilan ialah sebuah kemampuan yang seseorang miliki dalam menyelesaikan tugasnya baik secara fisik maupun secara mental dalam suatu keadaan.

\section{Motivasi}

Motivasi kerja merupakan rangsangan dan dorongan yang mengakibatkan seseorang memiliki semangat dalam melakukan pekerjaan. Dalam kata lain motivasi kerja sebagai faktor pendorong internal yang berasal dalam diri seseorang atau dapat dikatakan sebagai motif untuk dapat menimbulkan perilaku dan perbuatan yang akan dilakukan (Rosmaini \& Tanjung, 2019). Motivasi ialah rangkaian dorongan yang diberikan kepada seseorang untuk melakukan tindakan agar dapat mencapai tujuan yang dicita-citakan (Arif et al., 2019). Motivasi biasanya muncul karena adanya kebutuhan yang belum terpenuhi atau karena adanya harapan yang diinginkan sehingga kondisi psikologis yang mendorong para pekerja untuk berusaha menghasilkan barang atau jasa agar suatu tujuan dapat tercapai (Nguyen et al., 2020). Motivasi adalah tentang memberi staf anda perpaduan yang tepat antara panduan, pengarahan,dan penghargaan sehingga mereka terinspirasi dan tertarik untuk bekerja sesuai keinginan perusahaan (Nurun et al., 2017). Pengukuran yang digunakan adalah pengukuran menurut (Sutrisno, 2016) yaitu kebutuhan fisiologis, kebutuhan rasa aman, kebutuhan hubungan sosial, kebutuhan penghargaan, dan kebutuhan aktualisasi diri.

\section{Hubungan antar Variabel}

Sikap (attitude), pengetahuan (knowledge), dan kemampuan atau keterampilan (skill) merupakan kompetensi yang harus dimiliki karyawan, karena kompetensi merupakan sesuatu yang diperlukan oleh perusahaan, semakin besar kompetensi yang dimiliki oleh karyawan, maka semakin meningkat kinerjanya (Budiman et al., 2019). Kemampuan yang didasari oleh pengetahuan dan keterampilan, yang didukung dengan pelaksanaan tugas dan pekerjaan serta sikap kerja di tempat kerja, yang sesuai dengan standar kerja yang diterapkan oleh perusahaan merupakan sebuah kompetensi yang harus dimiliki karyawan (Sutrisno, 2016). Sehingga kompetensi ialah sesuatu hal yang penting dalam meningkatkan kinerja, hal tersebut didukung oleh Ardiansyah \& Sulistiyowati (2018) dan Soetrisno \& Gilang (2018) yang menyatakan ada pengaruh yang positif dan signifikan baik secara parsial dan simultan antara kompetensi terhadap kinerja. Hal tersebut memiliki arti semakin meningkatnya kompetensi dari karyawan maka akan memiliki dampak pada peningkatan kinerja dari karyawan. Namun Ratnasari (2016) mengatakan bahwa kompetensi tidak mempunyai pengaruh signifikan terhadap kinerja karyawan. Hal itu terjadi karena materi pelatihan dan kompetensi seperti perilaku karyawan, sikap, keahlian dan aspek pengetahuan belum optimal.

H1: Diduga kompetensi mempunyai pengaruh positif dan signifikan terhadap kinerja karyawan.

Osabiya (2015) menjelaskan bahwa motivasi karyawan menentukan kesuksesan setiap aspek bisnis, oleh sebab itu perusahaan memiliki peran penting dalam memotivasi karyawannya karena dengan adanya motivasi, karyawan akan dapat meningkatkan kinerja dan mencapai prestasi kerja. Motivasi sangatlah berdampak bagi karyawan karena tanpa adanya motivasi, karyawan akan bekerja sesuai dengan apa yang diinginkan saja sehingga untuk mendapatkan hasil pekerjaan yang sesuai standar atau bahkan melebihi standar, karyawan membutuhkan sebuah motivasi yang lebih agar dapat mencapai hasil yang sesuai dengan standarnya (Ainanur \& Tirtayasa, 2018). Hal tersebut didukung oleh Budiman et al., (2019) dan Mariana et al. (2018) yang menyebutkan motivasi memiliki pengaruh positif dan signifikan terhadap kinerja. Namun Adha et al. (2019) menyebutkan motivasi kerja tidak memiliki pengaruh terhadap kinerja. 
Kartika Juanita Nurwin \& Agus Frianto. Pengaruh Kompetensi dan Motivasi terhadap Kinerja Karyawan Perusahaan Asuransi

H2: Diduga motivasi kerja mempunyai pengaruh yang positif dan signifikan terhadap kinerja karyawan.

Ada bermacam-macam usaha yang dapat dipergunakan oleh perusahaan untuk upaya dalam meningkatkan kinerja dari karyawan, yaitu dengan meningkatkan kompetensi yang dimiliki karyawan dan memberikan motivasi pada karyawan. Kompetensi mempunyai pengaruh terhadap peningkatakan kinerja dari karyawan, semakin besarnya kompetensi yang dimiliki maka akan semakin besar pula kinerja dari karyawan. Begitu juga dengan motivasi, motivasi memiliki pengaruh untuk meningkatkan kinerja karyawan, semakin besar motivasi kerja yang diberikan terhadap karyawan, maka kinerja karyawan tersebut akan semakin besar (Anjani, 2019). Kinerja yang baik secara produktifitas, harus dilengkapi dengan kompetensi yang berhubungan dengan pengetahuan, latar belakang pendidikan, keahlian/pengetahuan, dan keterampilan serta memiliki motivasi kerja yang tinggi (Rosmaini \& Tanjung, 2019).

H3: Diduga kompetensi dan motivasi mempunyai pengaruh positif dan signifikan terhadap kinerja karyawan.

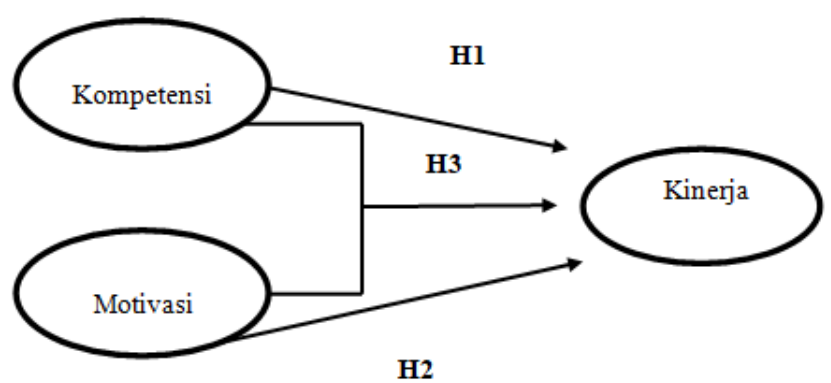

Gambar 1. KERANGKA PENELITIAN

\section{METODE PENELITIAN}

Penelitian ini menggunakan penelitian kuantitatif dengan menggunakan sumber data primer yang merupakan data hasil observasi langsung dengan objek penelitian dan data sekunder yang berasal dari sumber literasi pelengkap. Teknik pengumpulan data penelitian ini memakai metode wawancara dan kuisoner dengan item pernyataan untuk variabel kompetensi,motivasi dan kinerja karyawan. Populasi yang dipergunakan dipenelitian ini adalah seluruh karyawan PT. Asuransi Umum Bumi Putera Muda Unit Syariah Surabaya dengan jumlah total 35 orang. Seluruh karyawan tersebut dijadikan sebagai sampel sehingga pengambilan sampel yang dipergunakan pada penelitian ini memakai teknik sampel jenuh. Teknik analisis data pada penelitian ini menggunakan uji validitas, uji reliabilitas, uji asumsi klasik yang terdiri dari uji normalitas, uji multikolinearitas, uji heteroskedastisitas, dan uji auto korelasi. Selain itu regresi linear berganda, koefisien determinasi, uji T, dan uji $\mathrm{F}$ juga digunakan sebagai teknik analisis data dengan menggunakan software SPSS.

\section{HASIL DAN PEMBAHASAN}

Pada penelitian ini jumlah responden yang diambil sebesar 35 responden yang mana terdiri dari 19 responden laki-laki atau sebesar 54,2\% sedangkan responden perempuan berjumlah 16 responden atau sebesar $45,7 \%$. Berdasarkan usia responden terdapat 17 responden atau 48,5\% yang memiliki rentang interval usia 20-30 tahun, 9 responden atau 25,7\% memiliki rentang interval usia 31-40 tahun , 7 responden atau $20 \%$ memiliki rentang interval usia 41-50th dan 2 responden atau 5,7\% memiliki rentang interval usia 51-60 tahun.

Pendidikan terakhir responden yang berada di jenjang S2 berjumlah 3 responden atau sebesar 8,5\%. 27 responden atau sebesar 77,1\% memiliki pendidikan terakhir S1. 5 responden atau sebesar $14,2 \%$ berpendidikan terakhir SLTA. Status pernikahan responden di penelitian ini yaitu sebanyak 19 
responden atau sebesar 54,2\% berstatus sudah menikah dan 16 responden atau sebesar 45,7\% berstatus belum menikah.

\section{Hasil Uji Validitas dan Uji Reliabilitas}

Uji validitas dipergunakan untuk menguji valid dan tidaknya suatu angket. Angket dinyatakan valid apabila pernyataan pada angket dapat menerangkan sesuatu yang dapat diukur. Uji signifikansi dilakukan dengan cara membandingkan nilai corralated item total correlation ( $\mathrm{r}$ hitung) dan $\mathrm{r}$ tabel. Apabila $\mathrm{r}$ hitung $>\mathrm{r}$ tabel dapat dikatakan pernyataan tersebut valid. Pengukuran tersebut menggunakan kententuan $\mathrm{df}=\mathrm{n}-2$, yang mana pada penelitian ini mempunyai df sebesar 33 sehingga $\mathrm{r}$ tabel pada penelitian ini sebesar 0,344. Hasil uji validitas pada setiap variabel pada semua pernyataan terbukti valid karena hasil pengolahan data menunjukkan $r$ hitung $>r$ tabel. Sedangkan hasil uji reliabilitas dipergunakan untuk mengukur sebuah angket. Angket tersebut dapat dikatakan reliabel apabila jawaban dari responden konsisten. Setiap variabel dikatakan reliabel apabila hasil nilai cronchbach alpha $>0,70$. Berdasarkan hasil uji reliabilitas diketahui cronchbach alpha sebesar 0,968 yang mana nilai tersebut $>0,70$, sehingga dikatakan reliabel.

Tabel 1.

UJI ASUMSI KLASIK

\begin{tabular}{lcccc}
\hline \multicolumn{1}{c}{ Variabel } & Normalitas & Autokorelasi & \multicolumn{2}{c}{ Multikolinieritas } \\
& Sig. & DW & Tolerance & VIF \\
\hline &, 549 & 1,857 & & \\
Kompetensi (X1) & & &, 349 & 2,867 \\
Motivasi Kerja (X2) & & &, 349 & 2,867 \\
\hline Sumber: Output SPSS (2021, data diolah) & & &
\end{tabular}

Sumber: Output SPSS (2021, data diolah)

\section{Uji Normalitas}

Uji normalitas pada penelitian ini memakai uji normalitas kolmogorov smirnov yang mana uji ini memiliki tujuan untuk menguji variabel dependen dan independen berdistribusi normal atau tidak dalam model regresi (Sujarweni, 2015). Pengambilan keputusan pada uji normalitas kolmogorov smirnov ialah jika hasil nilai signifikansi $>0,05 \%$ maka variabel berdistribusi normal dan jika hasil nilai signifikansi $<0,05 \%$ maka variabel tersebut tidak berdistribusi normal. Dilihat pada tabel 1, nilai signifikansi memiliki nilai sebesar 0,549, sehingga dapat diartikan bahwa nilai signifikansi tersebut > 0,05 , yang artinya berdistribusi normal.

\section{Uji Multikolinearitas}

Berdasarkan tabel 1 , variabel kompetensi memiliki hasil nilai tolerance 0,349 dan hasil nilai VIF 2,867 begitu juga dengan variabel motivasi kerja hasil nilai tolerance 0,349 dan hasil nilai VIF 2,867. Hal tersebut menunjukkan bahwa nilai tolerance pada setiap variabel $>0,100$ dan nilai VIF pada setiap variabel $<10,00$, sehingga tidak terjadi gejala multikolinearitas.

\section{Uji Heteroskedastisitas}

Heteroskedastisitas dapat terjadi dengan melihat pola pada grafik scatterplot. Apabila pada grafik scatterplot tidak terjadi pola yang jelas dan titik-titik menyebar di sekitar angka 0 maka heteroskedastisitas tidak terjadi. Dari gambar 2, heteroskedastisitas tidak terjadi karena pada grafik tersebut tidak ada pola dan titik-titik menyebar di sekitar angka 0 serta tersebar secara acak.

\section{Uji Autokorelasi}

Uji autokorelasi timbul disebabkan karena tidak bebasnya antara hasil observasi dengan hasil observasi berikutnya. Nilai Durbin Watson (dw) sebagai alat pembanding ada atau tidaknya autokorelasi. Hasil perhitungan dibandingkan dengan Durbin Watson menggunakan derajat kepercayaan 5\%, apabila nilai dw terletak di antara du sampai dengan 4-du maka tidak terjadi gejala autokorelasi (Sujarweni, 2015). 
Kartika Juanita Nurwin \& Agus Frianto. Pengaruh Kompetensi dan Motivasi terhadap Kinerja Karyawan Perusahaan Asuransi

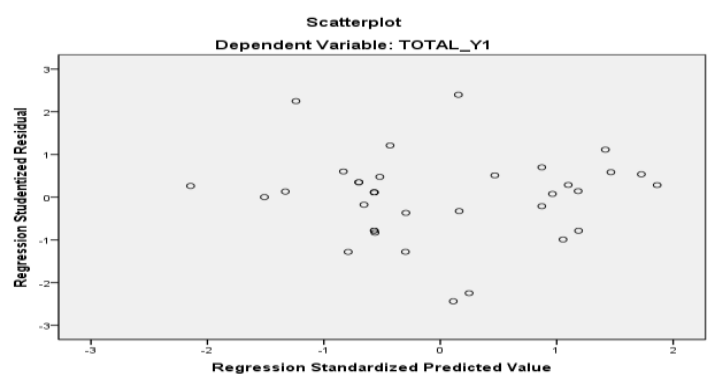

Sumber: Output SPSS (2021, data diolah)

Gambar 2. OUTPUT SCATTERPLOTS

Nilai Durbin Watson pada tabel 1 diketahui sebesar 1,5838 hal tersebut diketahui dari jumlah variabel bebas $(\mathrm{k})=2$ dan total responden $(\mathrm{n})=35$. Hasil Durbin Watson hitung sebesar 1,857 , sehingga nilai durbinwatson hitung terletak antara $1,5838<1,857<2,4162$ yang berarti tidak ada gejala autokorelasi.

\section{Regresi Linear Berganda}

Persamaan regresi linear berganda pada penelitian ini dapat dilihat di persamaan (1).

$\mathrm{Y}=1,22+0,539 \mathrm{X} 1+0,176 \mathrm{X} 2+\mathrm{e}$

\section{Koefisien Determinasi}

Koefisien determinasi dipergunakan untuk mengukur berapa besar kontribusi perubahan variabel dependen yang disebabkan oleh variabel independen. Apabila nilai dari koefisien determinasi besar maka semakin besar pula variabel independen dalam menerangkan pengaruhnya terhadap variabel dependen (Sujarweni, 2015).

Berdasarkan pada tabel 2, diketahui nilai $R$ Square 0,763 hal ini dapat diartikan pengaruh kompetensi sebagai X1 dan motivasi sebagai X2 secara simultan terhadap kinerja sebagai Y adalah sebesar $76,3 \%$, sedangkan sisanya $23,7 \%$ dijelaskan oleh faktor lain di luar model penelitian.

\section{Uji T}

Dari tabel 2, diketahui t tabel sebesar 2,03 sedangkan t hitung pada variabel kompetensi sebesar 4,754 dan $t$ hitung pada variabel motivasi sebesar 1,457 , sehingga pada variabel kompetensi t hitung $>t$ tabel sedangkan pada variabel motivasi $t$ hitung $<\mathrm{t}$ tabel. Begitu juga dengan hasil dari nilai signifikansi pada variabel kompetensi nilai signifikansi $<0,05$ sedangkan pada variabel motivasi nilai signifikansi $>0,05$. Maka dari hasilnya dapat diketahui bahwa variabel kompetensi (X1) memiliki pengaruh positif dan signifikan dengan variabel kinerja (Y) sedangkan variabel motivasi (X2) memiliki pengaruh positif dan tidak signifikan dengan variabel kinerja $(\mathrm{Y})$.

Tabel 2

HASIL UJI REGRESI LINEAR BERGANDA

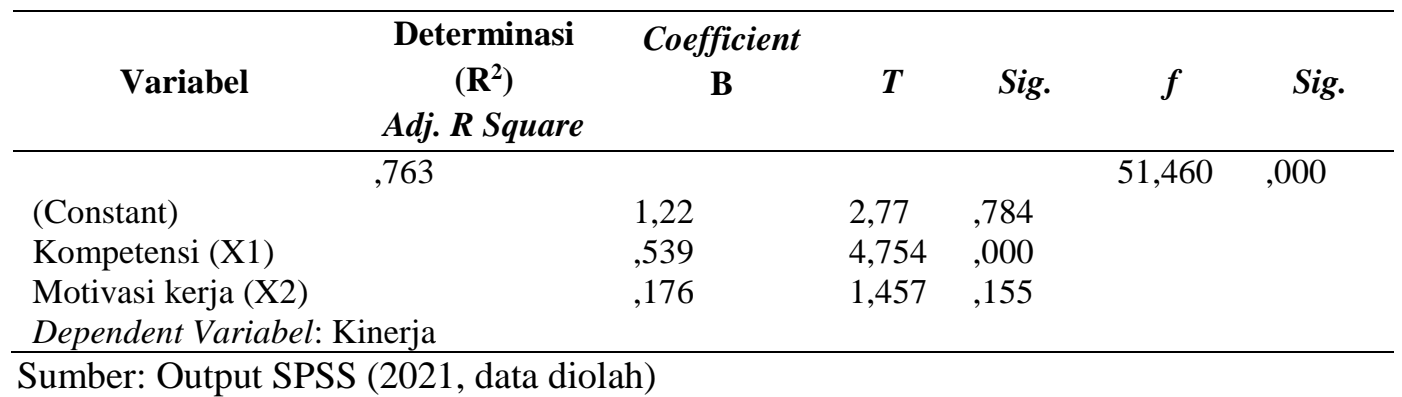




\section{Uji F}

Uji f dipergunakan untuk mengetahui berapa besar pengaruh variabel independen terhadap variabel dependen, uji $\mathrm{f}$ dapat juga dipergunakan untuk mengetahui bagaiamana kedua variabel independen dapat digunakan secara bersama-sama untuk memprediksi variabel dependen. Jika hasil dari nilai signifikansi $<0,05$ dan nilai $\mathrm{f}$ hitung $>\mathrm{f}$ tabel maka secara simultan $\mathrm{X}$ berpengaruh dengan $\mathrm{Y}$ (Sujarweni, 2015).

Sesuai tabel 2, f tabel ialah sebesar 3,28 sedangkan $\mathrm{f}$ hitung ialah sebesar 51,46 dan nilai signifikansi pada hasil tabel tersebut $<0,05$. Sehingga variabel kompetensi (X1) dan variabel motivasi (X2) secara simultan berpengaruh terhadap variabel kinerja $(\mathrm{Y})$.

\section{Pengaruh Kompetensi terhadap Kinerja Karyawan}

Dari hasil penelitian, variabel kompetensi berpengaruh secara positif dan signifikan terhadap kinerja karyawan. Kompetensi merupakan karakteristik dasar seseorang yang memungkinkannya untuk berprestasi unggul dalam diri pekerjanya dan seseorang dapat dikatakan kompeten apabila orang tersebut memiliki keterampilan dalam melakukan pekerjaan dan sangat jarang atau tidak pernah melakukan kesalahan (Ridwan, 2020). Kompetensi menunjukkan ciri-ciri pengetahuan dan keterampilan yang dimiliki atau dibutuhkan individu untuk memungkinkan mereka melaksanakan tugas dan tanggung jawab mereka secara efektif dan untuk meningkatkan standar kualitas profesional dalam pekerjaan mereka (Kurniawan et al., 2018).

Hal tersebut sejalan dengan Ardiansyah \& Sulistiyowati (2018), Soetrisno \& Gilang (2018), dan Ranstesalu et al. (2017) yang menyatakan ada pengaruh yang positif dan signifikan baik secara parsial dan simultan antara kompetensi dan kinerja. Hal tersebut memiliki arti bahwa semakin meningkatnya kompetensi dari karyawan maka akan berdampak pada peningkatan kinerja karyawan. Namun dalam Ratnasari (2016) dan Aima et al. (2017) yang dilakukan dibidang industri elektronik dan bank menyebutkan bahwa kompetensi tidak memiliki pengaruh signifikan dengan kinerja karyawan. Hal itu terjadi karena materi pelatihan dan kompetensi seperti perilaku karyawan, sikap, keahlian dan aspek pengetahuan belum optimal.

Hal itu sesuai dengan hasil wawancara yang dilakukan dengan salah satu karyawan yang menyatakan bahwa kompetensi karyawan sangat dibutuhkan karena perusahaan tersebut memiliki banyak produk asuransi sehingga membutuhkan kompetensi lebih dalam menangani hal tersebut. Sehingga, semakin besar kompetensi yang seorang karyawan miliki maka kinerja yang dilakukan akan semakin baik.

\section{Pengaruh Motivasi Kerja terhadap Kinerja Karyawan}

Sesuai dengan hasil uji yang telah dilaksanakan variabel motivasi kerja berpengaruh positif tidak signifikan terhadap kinerja karyawan. Yang mana hal tersebut bertentangan dengan teori yang ada, apalagi teori motivasi secara umum menyatakan bahwa apabila seseorang memiliki motivasi yang tinggi maka akan memiliki kinerja yang lebih baik daripada yang lain. Motivasi sebagai proses yang merangsang seseorang bertindak sesuai dengan apa yang diinginkan (Subari \& Raidy, 2015). Motivasi diartikan sebagai semua kekuatan pendorong internal dan eksternal yang membuat individu melakukan suatu aktivitas, yang menentukan batasan dan bentuk aktivitas yang berorientasi pada pencapaian tujuan tertentu (Robescu \& Iancu, 2016).

Hasil penelitian ini tidak sesuai dengan hasil penelitian terdahulu yaitu dari Budiman et al. (2019), Mariana et al. (2018), dan Sumenege (2016) yang dilakukan pada perusahaan dagang, kantor dinas dan perusahaan PLN yang menyebutkan motivasi berpengaruh positif dan signifikan dengan kinerja karyawan. Namun Adha et al. (2019) dan Irawan et al. (2020) menyebutkan bahwa motivasi kerja tidak berpengaruh terhadap kinerja karyawan.

Hal tersebut sesuai dengan hasil wawancara yang mana hasil wawancara tersebut yaitu menyatakan bahwa karyawan menyadari akan adanya kewajiban yang harus dikerjakan sehingga karyawan mengerjakan kewajibannya dengan kesadaran diri sendiri. Di sisi lain, para karyawan juga sudah 
Kartika Juanita Nurwin \& Agus Frianto. Pengaruh Kompetensi dan Motivasi terhadap Kinerja Karyawan Perusahaan Asuransi

merasa bahwa gaji dan tunjangan yang diterima dari perusahaan tersebut sudah cukup sehingga kebutuhan sudah terpenuhi dan motivasi yang diberikan tidak memengaruhii dari kinerja karyawan.

\section{KESIMPULAN}

Berdasarkan dari hasil pengolahan proses data dan analisis yang telah dilaksanakan dapat ditarik kesimpulan bahwa kompetensi memiliki pengaruh yang positif dan signifikan dengan kinerja karyawan, yang mana hasil tersebut menandakan bahwa H1 diterima. Motivasi kerja memiliki pengaruh positif namun tidak signifikan,yang mana hasil tersebut menandakan bahwa H2 ditolak. Secara simultan, kompetensi dan motivasi berpengaruh positif dan signifikan terhadap kinerja karyawan, sehingga H3 diterima. Dari hasil penelitian rekomendasi untuk perusahaan adalah mengembangkan kompetensi yang sudah dimiliki karyawan dengan cara memberikan pelatihanpelatihan untuk mengambangkan kemampuan, pengetahuan dan ketrampilan. Perusahaan juga dapat memberikan pembinaan dan coaching dari atasan terhadap bawahan mengenai pengetahuan dan ketrampilan agar dapat meningkatkan kompetensi karyawan. Selain itu, perusahaan dapat memberikan motivasi yang lebih terhadap karyawan karena motivasi yang telah diberikan kepada karyawan tidak mempunyai pengaruh terhadap kinerja karyawan, motivasi tersebut dapat berupa pendekatan yang dilakukan oleh atasan kepada bawahan. Penelitian selanjutnya dapat menggunakan variabel lain seperti beban kerja, kepuasan kerja, kompensasi dan produktivitas kerja, dan juga dapat meneliti pada bidang lain seperti pada bidang kesehatan, pertambangan, dan koperasi.

\section{DAFTAR PUSTAKA}

Adha, R. N., Qomariah, N., \& Hafidzi, A. H. (2019). Pengaruh Motivasi Kerja, Lingkungan Kerja, Budaya Kerja terhadap Kinerja Karyawan Dinas Sosial Kabupaten Jember. Jurnal Penelitian IPTEKS, 4(1), 47. https://doi.org/10.32528/ipteks.v4i1.2109

Ainanur, A., \& Tirtayasa, S. (2018). Pengaruh Budaya Organisasi, Kompetensi dan Motivasi terhadap Kinerja Karyawan. Maneggio: Jurnal Ilmiah Magister Manajemen, 1(1), 1-14. https://doi.org/10.30596/maneggio.v1i1.2234

Anjani, A. (2019). Pengaruh Kompetensi dan Motivasi Kerja terhadap Kinerja Karyawan. Jurnal Inspirasi Bisnis Dan Manajemen, 3(1), 1-10. http://jurnal.unswagati.ac.id/index.php/jibm/article/view/2191/pdf

Ardiansyah, Y., \& Sulistiyowati, L. H. (2018). Pengaruh Kompetensi dan Kecerdasan Emosional terhadap Kinerja Pegawai. Jurnal Inspirasi Bisnis Dan Manajemen, 2(1), 91. https://doi.org/10.33603/jibm.v2i1.1064

Arif, S., Zainudin, Z., \& Hamid, A. (2019). Influence of Leadership, Organizational Culture, Work Motivation, and Job Satisfaction of Performance Principles of Senior High School in Medan City. Budapest International Research and Critics Institute (BIRCI-Journal): Humanities and Social Sciences, 2(4), 239-254. https://doi.org/10.33258/birci.v2i4.619

Budiman, N. P., Searang, I. S., \& Sendow, G. M. (2019). Pengaruh Kompetensi, Motivasi, dan Disiplin Kerja terhadap Kinerja Karyawan (Studi Pada Pt. Hasjrat Abadi Tendean Manado). Journal of Chemical Information and Modeling, 53(9), 1689-1699. https://doi.org/org/10.35794/emba.v4i3.13726

Chumba, R. J., Obonyo, P. P. K., Chumba, R. J., Obonyo, P. P. K., Muindi, F., \& Njihia, J. (2018). Moderating Effect of Employee Competence on the Relationship between Employee Reward and Nurses' Job Perfomance in Kenyan National Referral Hospitals. Stratford Peer Reviewed Journals and Book Publishing Journal of Human Resource \& Leadership, 2(5), 1-23. https://stratfordjournals.org 
Distyawaty, D. (2017). Pengaruh Kompetensi dan Pengembangan Karir terhadap Kinerja Aparatur Pengawas Inspektorat Daerah Provinsi Sulawesi Tengah. Katalogis Journals, 5(4), 56-68. http://jurnal.untad.ac.id/jurnal/index.php/Katalogis/article/view/8919

Dwiyanti; (2019). Pengaruh Kompetensi dan Motivasi Kerja terhadap Kinerja Karyawan di PD BPR Bank Buleleng 45. Jurnal Manajemen Dan Bisnis, 1(2), 121-130. https://doi.org/http://dx.doi.org/10.23887/pjmb.v1i2.23154

Edison, E., Yohny, A., \& Imas, K. (2017). Manajemen Sumber Daya Manusia (Strategi dan Perubahan Dalam Rangka Meningkatkan Kinerja Pegawai dan Organisasi). Bandung: Alfabeta.

Hasyim, M. A. N., Maje, G. I. L., Alimah, V. ', \& Priyadi, S. A. P. (2020). Pengaruh Motivasi dan Disiplin Kerja terhadap Kinerja Karyawan PT.Kahatex. Jesya (Jurnal Ekonomi \& Ekonomi Syariah), 3(2), 58-69. https://doi.org/10.36778/jesya.v3i2.161

Kurniawan, D. A., Guswandi, \& Sodikin, A. (2018). the Effect of Competence and Motivation on Employee Performance Through Employees Capabilitieson Pt. Binasinar Amity. International Journal of Research Science \& Management, 5(5), 48-60. https://doi.org/10.5281/zenodo.1249804

Lutfiyah, Hening, W, O. (2020). Pengaruh Kompetensi dan Budaya Kerja terhadap Kinerja Karyawan. Jurnal Ilmu Manajemen, 8(3), 684-699. https://doi.org/10.23887/pjmb.v2i1.26274

Manda, D. (2018). The Effect of Reward System and Staff Competence Towards Working Perfomance Within The Faculty of Social Science. Atlantis Press Journals, 226(Icss), 966-969. https://www.atlantis-press.com/proceedings/icss-18/25903948

Mariana, N. N., Umar, A., \& Tamsah, H. (2018). Pengaruh Kompensasi, Kompetensi dan Motivasi terhadap Kinerja Pegawai pada Dinas Pekerjaan Umum dan Penataan Ruang di Kabupaten Bantaeng. YUME: Journal of Management, 1(2), 130-150. https://doi.org/https://doi.org/10.2568/yum.v1i2.237

Mariati. Mauludin Hanif. (2018). The Influence of Organizational Culture And Work Motivation on Employee Performance, Job Satisfaction As Intervening Variable ( Study On Secretariat Staff of Pasuruan Regency ). IOSR Journal of Business and Management (IOSR-JBM), 20(8), 30-39. https://doi.org/10.9790/487X-2008013039

Masinde, C., Prof, I., Obonyo, P. K., Muindi, F., \& Munjuri, M. (2019). Analysis of The Effect of Employee Age, Human Resource Management Practices and Employee Competence on Employee Performance in Kenyan State Corporations. European Journal of Business and Management, 11(30), 122-138. https://doi.org/10.7176/ejbm/11-30-14

Md. Nurun, N., Md. Monirul, I., Tanvir Mahady, D., \& Md. Abdullah, A. H. (2017). Arabian Journal of Business and Impact of Motivation on Employee Performances: A Case Study of Karmasangsthan Bank Limited, Bangladesh. Arabian Journal of Business and Management Review, 7(1), 1-8. https://doi.org/10.4172/2223-5833.1000293

Nguyen, P. T., Yandi, A., \& Mahaputra, M. R. (2020). Factors That Influence Employee Performance: Motivation, Leadership, Environment, Culture Organization, Work Achievement, Competence and Compensation (a Study of Human Resource Management Literature Studies). Dinasti International Journal of Digital Business Management, 1(2), 1-16. https://doi.org/10.31933/DIJDBM

Osabiya, B. J. (2015). the Effect of Employees Motivation on Organizational Performance. Journal of 
Kartika Juanita Nurwin \& Agus Frianto. Pengaruh Kompetensi dan Motivasi terhadap Kinerja Karyawan Perusahaan Asuransi

Public Administration and Policy Research, 7(4), 62-75. https://doi.org/10.5897/jpapr2014.0300

Purba, C. B., \& Gunawan, P. N. (2018). The Influence of Work Motivation, Organizational Culture and Career Development on Employee Performance in PT. Titis Sampurna Inspection. Saudi Journal of Business and Management Studies (SJBMS), 3(6), 629-640. https://scholarsmepub.com/

Putri, K. D. C., Sari, M. M. R., Ramantha, I. W., \& Budiasih, I. G. A. N. (2019). Effect of selfefficacy, competence and compensation in performance of financial manager on motivation as moderation. International Research Journal of Management, IT and Social Sciences, 6(3), 8393. https://doi.org/10.21744/irjmis.v6n3.635

Putu, I., Saputra, A., Bagia, W., Suwendra, W., \& Manajemen, J. (2016). Pengaruh Kompetensi dan Disiplin Kerja terhadap Kinerja Karyawan. Journal Bisma Universitas Pendidikan Ganesha Jurusan Manajemen, 4(1). https://ejournal.undiksha.ac.id/index.php/JMI/article/view/6715

Ratnasari, S. L. (2016). Pengaruh Kompetensi dan Kompensasi terhadap Kinerja Karyawan Departemen Quality Assurance Pt. Peb Batam. Prosiding Seminar Nasional Ekonomi Dan Bisnis, 1(1), 424-434. http://eprints.umsida.ac.id/id/eprint/138

Retningjati, A., Yunita, L., \& Sitorus, M. (2018). Effect of Competence And Work Motivation on Employee Performance PT. Rotella Mandiri Persada Perbaungan. Journal of Management Science (JMAS), 1(2), 2684-9747. http://exsys.iocspublisher.org/index.php/JMAS

Ridwan, M. (2020). Building behavior and performance citizenship: Perceived organizational support and competence (case study at SPMI private university in west Sumatra). International Journal of Psychosocial Rehabilitation., 24(6), 2049-2064. https://doi.org/doi.org/10.37200/IJPR/V24I6/PR260195

Robescu, O., \& Iancu, A.-G. (2016). The Effects of Motivation on Employees Performance in Organizations. Valahian Journal of Economic Studies, 7(2), 49-56. https://doi.org/10.1515/vjes2016-0006

Rosmaini, R., \& Tanjung, H. (2019). Pengaruh Kompetensi, Motivasi dan Kepuasan Kerja terhadap Kinerja Pegawai. Maneggio: Jurnal Ilmiah Magister Manajemen, 2(1), 1-15. https://doi.org/10.30596/maneggio.v2i1.3366

Soetrisno, A. P., \& Gilang, A. (2018). Pengaruh Kompetensi terhadap Kinerja Karyawan (Studi di PT. Telekomunikasi Indonesia Tbk Witel Bandung). JURISMA : Jurnal Riset Bisnis \& Manajemen, 8(1). https://doi.org/10.34010/jurisma.v8i1.998

Subari, S., \& Raidy, H. (2015). Influence of Training, Competence and Motivation on Employee Performance, Moderated by Internal Communications. International Journal of Economic Research, 12(4), 1319-1339. https://doi.org/10.11634/216796061504678

Sujarweni, W. (2015). Metodologi Penelitian-Bisnis \& Ekonomi. Yogyakarta : Pustakabarupres.

Sutrisno, E. (2016). Manajemen Sumber Daya Manusia. Jakarta : Kencana Prenada Media Group.

Wardani, N. K. (2017). Pengaruh Kemampuan, Pelatihan dan Motivasi Kerja terhadap Kinerja Karyawan Office PT. SMART Tbk. Jurnal Ilmu Dan Riset Manajemen, 6(5), 1-18. http://jurnalmahasiswa.stiesia.ac.id/index.php/jirm/article/view/1529

Wibowo. (2014). Manajemen Kinerja edisi keempat. Jakarta : Rajawali Pers. 